(C) Group of authors, 2019

UDC 616.379-008.64-07

DOI - https://doi.org/10.14300/mnnc.2019.14122

ISSN - 2073-8137

\title{
CAUSED VISUAL POTENTIALS IN EARLY DIAGNOSTICS IN PATIENTS WITH TYPE 1 DIABETES MELLITUS
}

\author{
Shtemberg L. V., Karpov S. M., Khojayan A. B., Kaloev A. D. \\ Stavropol State Medical University, Russian Federation \\ ВЫЗВАННЫЕ ЗРИТЕАЬНЫЕ ПОТЕНЦИААЫ \\ В РАННЕЙ АИАГНОСТИКЕ У БОАЬНЫХ \\ САХАРНЫМ АИАБЕТОМ 1 ТИПА
}

\author{
А. В. Штемберг, С. М. Карпов, А. Б. Ходжаян, А. А. Калоев \\ Ставропольский госуАарственный меАицинский университет, \\ Российская ФеАерация
}

Diabetes takes a leading place among the causes of blindness. One hundred three patients with type 1 diabetes mellitus (DM) aged from 18 to 45 years were examined with varying severity of visual disorders.Disease duration was from one year to 10 years. A neurophysiological examination was performed using visual evoked potentials on black-and-white (BW) and color (red-yellow (RY) and green-black (GBk))changing chess pattern(CCP). The results obtained in terms ofVEPindices made it possible to note that in all patients of the study group conduction disturbances were detected in the visual fibers of the analyzer, namely, an increase in the peak latency (PL) of P100 and a decrease in the amplitude of the wave (WA) N75-P100 with an earlier prevalence of disorders in the color-changing CCP relative toBW. The study has shown that in type 1 DMcolor vision as the most subtle structural element of the VAis primarily affected.

Keywords: diabetes, evoked visual potentials, chess pattern

На сегодняшний день сахарный диабет занимает лидирующее место среди причин слепоты. В исследование были включены 103 пациента в возрасте от 18 до 45 лет с сахарным диабетом 1 типа, имеющих различную степень выраженности зрительных расстройств. Длительность заболевания составляла 1-10 лет. Больным проведено клиническое, неврологическое и нейрофизиологическое обследование с использованием зрительных вызванных потенциалов на черно-белый и цветной (красно-желтый и зелено-черный) сменяющийся шахматный паттерн. Полученные результаты по показателям зрительных вызванных потенциалов позволили отметить, что у всех больных были выявлены нарушения проводимости по волокнам зрительного анализатора, а именно - увеличение пиковой латентности P100 и снижение амплитуды волны N75-P100 с более ранним преобладанием расстройств на цветной сменяющийся шахматный паттерн относительно черно-белого. Данное исследование доказывает, что при сахарном диабете1 типа в первую очередь страдает цветное зрение как наиболее тонкий структурный элемент зрительного анализатора.

Ключевые слова: сахарный диабет, зрительные вызванные потенциалы, шахматный паттерн

For citation: Shtemberg L. V., Karpov S. M., Khojayan A. B., Kaloev A. D. CAUSED VISUAL POTENTIALS IN EARLY DIAGNOSTICS IN PATIENTS WITH TYPE 1 DIABETES MELLITUS. Medical News of North Caucasus. 2019;14(3):497-500. DOI - https://doi.org/10.14300/mnnc.2019.14122

Для цитирования: Штемберг Л. В., Карпов С. М., Ходжаян А. Б., Калоев А. Д. ВЫЗВАННЫЕ ЗРИТЕЛЬНЫЕ ПОТЕНЦИАЛЫ В РАННЕЙ ДИАГНОСТИКЕ У БОЛЬНЫХ САХАРНЫМ ДИАБЕТОМ 1 ТИПА. МеДИЦИНСКИЙ вестнИК СеверНОГО Кавказа. 2019;14(3):497-500. DOI - https://doi.org/10.14300/mnnc.2019.14122

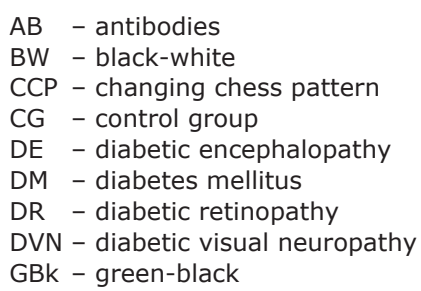

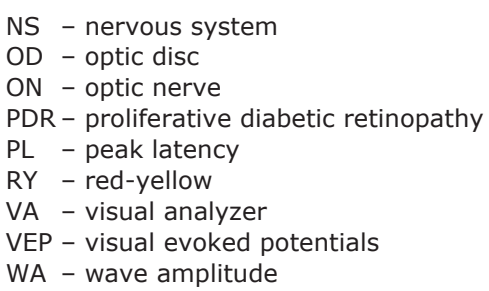


$\mathrm{T}$ he problem of diabetes mellitus (DM) is global and is a hidden epidemic. We have to admit that the number of patients with this pathology increases annually and includes most of the working-age group, leading to a persistent visual impairment [1, 2, 3]. Diabetes takes a leading place among the causes of blindness. In this regard, a detailed study of the visual analyzer (VA) is of particular importance $[4,5,6]$.

The purpose of the study was to clarify the criteria for the diagnosis of visual disturbances using VEP for a CCP in patients with type $1 \mathrm{DM}$.

Material and Methods. In our work, 103 patients with a diagnosis of type $1 \mathrm{DM}$ with a disease experience of 1-10 years were examined, 65 of them were women, 38 men of the age category from 18 to 45 years old. The study was conducted from 2014 to 2018 based on the Department of Endocrinology, Functional Diagnostics of the City Clinical Hospital № 3 (Stavropol). The main group consisted of patients suffering from type $1 \mathrm{DM}$. The inclusion criteria were presented: the presence of type $1 \mathrm{DM}$; age from 18 to 45 years; disease in the stage of sub compensation; experience of the disease for at least 1 year and no more than 10 years; the absence of changes in the fundus of the eye, or the initial stage of diabetic retinopathy. Exclusion criteria were: age less than 18 and more than 45 years; decompensated disease; the experience of the disease is less than 1 year and more than 10 years; previous carried over neuroinfectionof the prior generation, traumatic brain injury; hypersensitivity to alpha-lipoic acid; the presence of cancer, cardiovascular, hepatic or renal failure; pregnancy and the period of breastfeeding; eye injuries. As a comparison, a control group was used, which included 30 healthy young people aged 18 to 30 years, including twenty women andten men. The group was formed to compare the initial changes in the structure of VA and cognitive potential.

All studied patients underwent a neurological examination, a neurophysiological study using the VEP technique for colors and BW CCP, immunological determination of the content of antibodies $(A B)$ to the main myelin protein (MMP) in blood serum.

Statistical data processing was performed using variation statistics in the licensed computer program «Statistica 10.0» (StatSoft, USA). The level of statistical error was set at 0.05 .

Results and Discussion. Type $1 \mathrm{DM}$, in typical cases, makes a clear clinical picture, which develops over several months or even weeks. The manifestation of this disease can provoke infectious and other concomitant pathology.

Our research work indicated that in most patients with type $1 \mathrm{DM}$ manifests itself in various clinical forms, which are based on its effect on the nervous system (NS). The examined patients had a combination of clinical manifestations and complications of type $1 \mathrm{DM}$, such as encephalopathy, diabetic visual neuropathy (DVN), distal polyneuropathy, and vegetative-trophic disorders. In this case, the dominant clinical manifestations of DM were taken as the basis.

In 37 (35.9\%) patients, diabetic visual neuropathy was determined. Patients of the study group presented subjective complaints of decreased visual acuity, the appearance of «flashing dots», "curtain», «fog» before the eyes, indicates the vascular origin of these disorders. Also, clinical manifestations of this pathology were lacrimation and periodically occurring disturbances in the perception of visual images.

Polyneuritic disorders were detected in the form of numbness, pain, a feeling of coldness in the distal limbs in $33(32.0 \%)$ patients. Clinically, patients noted hypesthesia, fading reflexes, and hypotension.

In $26(25.2 \%)$ patients, encephalopathy was diagnosed, which was characterized by the following complaints: pronounced general weakness and fatigue, the appearance of anxiety, a decrease in concentration, working capacity combined with vegetative-vascular disorders, as well as persistent memory impairment mainly short term basis. Also, headaches of a compressive nature were noted that occurred for no apparent reason, regardless of the time of day. A change in mood, mainly depression, a decrease in interests, drowsiness, attacks of anger and dreary mood, emotional liability, insomnia in the form of difficulty falling asleep and frequent night awakenings were revealed.

It should also be noted that in 7 (6.8 \%) patients, vegetative-trophic disorders in the form of diabetic osteoarthropathy were recorded.

We paid particular attention to the formation of visual axonopathy as a complication of the underlying disease, which significantly affects the patient's quality of life. In this regard, it was of interest to study visual disturbances taking into account early disturbances in light perception both on BW and the color spectrum of light. It should be noted that the experiment on color perception was carried out in a few studies, as indicated by isolated publications, mainly by foreign authors $[7,9]$. In this regard, we evaluated the neurophysiological criteria for conducting pathways for using VEP on both BW and color RY, GBk CCP.

When studying the results of VEP on BW and CCP it was determined that in the study group of patients revealed a statistically significant $(p<0.01)$ increase in PLP100 on the right and left $(121.3 \pm 3.67 \mathrm{~ms})$, a decrease in WA P100 $(2.4 \pm 1.11 \mu \mathrm{V})$, which indicates a violation of the response of visual neurons relative to the control group (CG) (101.1 $\pm 1.79 \mathrm{~ms})$. The obtained data are shown in Table 1. This, in turn, allows us to state the fact that a change in the results of PL and WA can only be observed in patients with type $1 \mathrm{DM}$ lasting more than seven years, which does not allow deviations in patients with a short history of the disease according to indicators.

The results of the peak latency of the VEP

Table 1 on the BWCCP in the main and control groups $(\mathrm{M} \pm \mathrm{m})$

\begin{tabular}{|l|c|c|}
\hline \multicolumn{1}{|c|}{ Period } & $\begin{array}{c}\text { Main group } \\
(n=103)\end{array}$ & $\begin{array}{c}\text { Control group } \\
(n=30)\end{array}$ \\
\hline $\begin{array}{l}\text { Peak latency }(\mathrm{ms}) \\
\text { N75 }\end{array}$ & $72.2 \pm 1.68$ & $68.1 \pm 3.04$ \\
\hline P100 & $121.3 \pm 3.67$ & $101.1 \pm 1.79$ \\
\hline N145 & $175.2 \pm 1.45$ & $148.3 \pm 2.02$ \\
\hline Amplitude $(\mu \mathrm{V})$ P100 & $2.4 \pm 1.11$ & $9.1 \pm 1.13$ \\
\hline
\end{tabular}

In our study, the most significant were the results of VEP on color CCP. RYCCP allowed assessing the pathophysiological changes in the system of photoreceptors (cones) involved in the formation of color vision. In the study group of patients with type $1 \mathrm{DM}$, when analyzing the results, a statistically significant $(p<0.01)$ increase in PL P100 on the right and left was found to be $147.3 \pm 2.05 \mathrm{~ms}$ (control 102.1 $\pm 1.72 \mathrm{~ms}$ ), and a decrease 


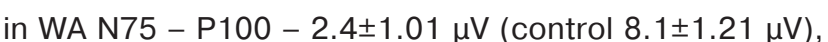
which, in turn, indicates a violation of the strength of the response to the photoreaction [8]. The data are presented in Table 2.

Table 2

Indicators of the peak latency of the VEPon the RYCCP in the main and control groups

\begin{tabular}{|l|c|c|}
\hline \multicolumn{1}{|c|}{ Period } & $\begin{array}{c}\text { Main group } \\
(\mathrm{n}=103)\end{array}$ & $\begin{array}{c}\text { Control group } \\
(\mathrm{n}=30)\end{array}$ \\
\hline $\begin{array}{l}\text { Peak latency }(\mathrm{ms}) \\
\text { N75 }\end{array}$ & $115.2 \pm 1.79$ & $72.1 \pm 2.09$ \\
\hline P100 & $147.3 \pm 2.05$ & $102.1 \pm 1.72$ \\
\hline N145 & $185.2 \pm 1.74$ & $151.3 \pm 2.22$ \\
\hline Amplitude $(\mu \mathrm{V})$ P100 & $2.4 \pm 1.01$ & $8.1 \pm 1.21$ \\
\hline
\end{tabular}

Our results of a study on GBk CCP indicated a significant increase in PL P100 on the right and left $141.3 \pm 3.78 \mathrm{~ms}$ compared with the CG (102.1 $\pm 1.72 \mathrm{~ms})$. WA N75 - P100 was statistically significantly reduced $(2.3 \pm 1.21 \mu \mathrm{V})$. The data are shown in Table 3 .

We can note that in all the patients examined by us, statistically significant $(p<0.01)$ neurophysiological deviations of VEP were revealed, namely, an increase in the peak latency of P100 and a decrease in WA of the main peaks with an earlier prevalence of disorders on the color spectrum relative to BW. In this regard, we believe that an increase in PL is a consequence of demyelination processes [11]. To clarify these mechanisms, we conducted an immunological study to determine the concentration oflg $\mathrm{G}$ antibodies to the myelin essential protein (MBP) [10]. On examining 45 patients with type $1 \mathrm{DM}$, it was found in the study group that the level of AT was significantly $(p<0.001)$ higher than the level of $\mathrm{CG}$ and amounted to $198.1 \pm 2.95 \mu \mathrm{g} / \mathrm{ml}$ (control group $48.1 \pm 0.78 \mu \mathrm{g} / \mathrm{ml}$ ). It should be noted that the concentration of antibodies to MBP tended to increase depending on the length of duration of DM: the longer the disease was, the higher their blood content. This fact indicates that the period of the disease in $73 \%$ of cases directly affects the formation of demyelination processes in the structures of the neurological system. This circumstance makes it possible to predict the course of the disease and makes it possible, taking into account this indicator, to assess the dynamics of DM, as well as the treatment that can be used in the future to identify the severity of the demyelinating process in patients with this disease.

Indicators of the peak latency of the VEPon the GBCCP in the main and control groups

\begin{tabular}{|l|c|c|}
\hline \multicolumn{1}{|c|}{ Period } & $\begin{array}{c}\text { Main group } \\
(n=103)\end{array}$ & $\begin{array}{c}\text { Control group } \\
(n=30)\end{array}$ \\
\hline $\begin{array}{l}\text { Peak latency }(\mathrm{ms}) \\
\text { N75 }\end{array}$ & $110.2 \pm 1.79$ & $72.1 \pm 2.09$ \\
\hline P100 & $141.3 \pm 3.78$ & $102.1 \pm 1.72$ \\
\hline N145 & $183.2 \pm 1.74$ & $151.3 \pm 2.22$ \\
\hline Amplitude $(\mu \mathrm{V})$ P100 & $2.3 \pm 1.21$ & $8.1 \pm 1.21$ \\
\hline
\end{tabular}

Conclusions. Neurophysiological results using VEP with immunological data indicate the presence of demyelination processes in the pathways VA, which leads to an increase in PL P100 and a decrease in WA N75 - P100. It should be noted that the shorter the wavelength of the light pulse, the higher the changes occur in the speed of the nerve impulse.

The obtained results also indicate that the extension of PL appears at earlier stages of significant clinical neurological manifestations, which can be used in the diagnosis of initial neurological disorders in patients with type $1 \mathrm{DM}$.

Analyzing the above data, we can conclude that the detection of optic disc disease in clinical practice should begin at the earliest possible time, in this regard; neurophysiological and immunological studies have allowed expanding the diagnostic search to identify the initial signs of visual disturbances to prevent complications and conduct appropriate pathogenic therapy.

Disclosures:

The authors declare no conflict of interest.

\section{References}

1. Dedov I. I. Diabetes mellitus - the most dangerous challenge to the world community. Vestn. Grew up Acad. Honey. Sciences. 2012;1:7-13.

2. Kalinin A. P., Kotov S. V., Rudakova I. G. Neurological disorders in endocrine diseases: hands. for doctors. 2nd ed. Moscow: MIA. 2009: 488.

3. Karpov S. M., Shtemberg L. V., Frantseva A. P. Definition of autoantibodies to myelin basic protein in patients with type 1 diabetes. Successes of modern science. 2014;6:131-132.

4. Dedova I. I., Melnichenko G. A. Endocrinology: national leadership. Moscow: GEOTAR-Media. 2019:246.

5. Zimmet P. Z., Magliano D. J., Herman W. H., Shaw J. E. Diabetes: a 21 st century challenge. Lancet Diabetes Endocrinol. 2014;2(1):56-66. https://doi.org/10.1016/S2213-8587(13)70112-8

6. Sarkar G., Alattar M., Brown R. J. [et al.] Exenatide Treatment for 6 Months Improves Insulin Sensitivity in Adults with Type 1 Diabetes Mellitus. Diabetes Care. 2014;37(3):666670. https://doi.org/10.2337/dc13-1473

7. Kan E., Kiliçkan E., Ayar A., Colak R. Effects of two antioxidants; $\alpha$-lipoic acid and fisetin against diabetic cataract in mice. Int. Ophthalmol. 2015;35(1):115-120. https://doi:10.1007/s10792-014-0029-3
8. Karpov S., Shtemberg L., Karpova E., Saneeva G., Muraviev $\mathrm{K}$. [et al.] Investigation of the optical analyzer for a changing color chess pattern in patients with diabetes 1 type. Journal of Neurological Sciences. 2017;381, Supplement: 494. https://doi.org/10.1016/j.jns.2017.08.3600

9. Pop A., Clenciu D. Anghel M. [et al.] Insulin resistance is associated withall chronic complications in type 1 diabetes. Rom Diane Study Group. J. Diabetes. 2016;8(2):220-228. https://doi.org/10.1111/1753-0407.12283

10. Lewis K. R., Clark C., Velarde M. C. Socioeconomic factors associated with pediatric diabetic ketoacidosis admissions in Southern West Virginia. Clin. Endocrinol. 2014;81(2):218221. https://doi.org/10.1111/cen.12350

11. Urbanová J., Rypáčková B., Procházková Z. [et al.] Positivity for islet cell autoantibodies in patients with monogenic diabetes is associated with later diabetes onset and higher HbA1c level. Diabet Med. 2014;31(4):466-471. https://doi.org/10.1111/dme.12314 


\title{
About authors:
}

Shtemberg Lyubov Valerievna, postgraduate student of the Department of neurology, neurosurgery and medical genetics, tel.: +79288189522; e-mail: sedakovaljuba@mail.ru; ORCID - 0000-0002-5818-2148

Karpov Sergei Mikhailovich, MD, Professor, Head of the Department of neurology, neurosurgery and medical genetics; tel.: +79054101523; e-mail: karpov25@rambler.ru

Khojayan Anna Borisovna, DMSc, Professor, Vice-rector for educational activities, Professor of Department of biology; tel.: +78652353442; e-mail: kafedrabiologii@stgma.ru

Kaloev Atsamaz Dziboevich, CMSc, Associate Professor, Head of Department of life safety and disaster medicine; tel.: +78652352496; e-mail: mob@stgma.ru

\section{EFFECTS OF BFB-THERAPY ON RESPIRATORY DYSFUNCTION AND ASTHENIA IN PATIENTS WITH PARKINSON'S DISEASE}

\author{
Kurushina O. V. ${ }^{1}$, Barulin A. E. ${ }^{1}$, Karpov S. M. ${ }^{2}$, Chernovolenko E. P. ${ }^{1}$ \\ ${ }^{1}$ Volgograd State Medical University, Russian Federation \\ 2 Stavropol State Medical University, Russian Federation
}

\section{КОРРЕКЦИЯ АЫХАТЕАЬНЫХ И АСТЕНИЧЕСКИХ ПРОЯВАЕНИЙ МЕТОАОМ БОС-ТЕРАПИИ У ПАЦИЕНТОВ С БОАЕЗНЬЮ ПАРКИНСОНА}

\author{
О. В. Курушина ${ }^{1}$, А. Е. Барулин ${ }^{1}$, С. М. Карпов ${ }^{2}$, Е. П. Черноволенко ${ }^{1}$ \\ ${ }^{1}$ ВолгограАский госуАарственный МеАицинский университет, Российская ФеАерация \\ 2 Ставропольский госУАарственный меАицинский университет, Российская ФеАерация
}

The pilot study was conducted to assess the effectiveness of the sensorimotor respiration control (SRC) method based on the biological feedback principle, in the complex correction of respiratory dysfunction and asthenia in 48 patients with Parkinson's disease. Initially, in all patients, there was identified a significant correlation between subjective respiratory disorders, biomechanical changes in the respiratory pattern and the respiratory cycle $(r=0.81)$, and varying degrees of asthenia. The severity of respiratory dysfunction ( $r=0.76)$, motor deficit $(r=0.71)$, asthenia $(r=0.81)$ and anxiety-depressive manifestations $(r=0.63)$ have a significant impact on the decline of the quality of patient's life. During course of treatment, there was a significant improvement in the parameters of the respiratory cycle, asthenia, quality of life and the psycho-emotional state of the patients $(r<0.05)$, the normopnoic version of the respiratory pattern was reached in $62.5 \%$ of patients $(p<0.05)$, and the physiological type of the respiratory pattern was achieved in $41.7 \%$ of patients.

Keywords: Parkinson's disease, respiratory dysfunction, asthenia, non-motor symptoms, BFB-therapy, quality of life

Пилотное исследование по оценке эффективности метода сенсомоторного управления дыханием (СуД) было основано на принципе биологической обратной связи в комплексной коррекции дыхательных и астенических нарушений у 48 пациентов с болезнью Паркинсона. Исходно у всех больных выявлена значимая корреляция между субъективными дыхательными нарушениями, биомеханическими изменениями дыхательного паттерна и дыхательного цикла $(r=0,81)$ и различной степенью выраженности астенического синдрома. Существенное влияние на снижение качества жизни оказывают выраженность дыхательных нарушений $(r=0,76)$, моторный дефицит $(r=0,71)$, астения $(r=0,81)$ и тревожно-депрессивные проявления $(r=0,63)$. В процессе лечения наблюдалось достоверное улучшение показателей дыхательного цикла, проявлений астении, качества жизни и психоэмоционального состояния пациентов $(r<0,05)$. У 62,5 \% больных удалось достигнуть нормопноического варианта дыхательного паттерна $(p<0,05), y$ 41,7\% пациентов - физиологического типа дыхательного паттерна.

Ключевые слова: болезнь Паркинсона, дыхательные нарушения, астения, немоторные симптомы, БОС-терапия, качество жизни

For citation: Kurushina O. V., Barulin A. E., Karpov S. M., Chernovolenko E. P. EFFECTS OF BFB-THERAPY ON RESPIRATORY DYSFUNCTION AND ASTHENIA IN PATIENTS WITH PARKINSON'S DISEASE. Medical News of North Caucasus. 2019;14(3):500-502. DOI - https://doi.org/10.14300/mnnc.2019.14123

Для цитирования: Курушина О. В., Барулин А. Е., Карпов С. М., Черноволенко Е. П. КОРРЕКЦИЯ ДЫХАТЕЛЬНЫХ И АСТЕНИЧЕСКИХ ПРОЯВЛЕНИЙ МЕТОДОМ БОС-ТЕРАПИИ У ПАЦИЕНТОВ С БОЛЕЗНЬЮ ПАРКИНСОНА. МЕДИЦИНский вестник Северного Кавказа. 2019;14(3):500-502. DOI - https://doi.org/10.14300/mnnc.2019.14123 